\title{
Forage cactus associated with different fiber sources for lactating Sindhi cows: intake, digestibility and microbial protein production
}

\section{Carla Aparecida Soares Saraiva1, Severino Gonzaga Neto ${ }^{1}$, Maria Fernanda Soares Queiroz ${ }^{2}$, Lara Toledo Henriques ${ }^{1}$, Edilson Paes Saraiva ${ }^{1}$, Rômulo Pontes de Freitas Albuquerque ${ }^{3}$, Vinicius de França Carvalho Fonseca ${ }^{4}$, George Vieira do Nascimento ${ }^{5}$}

\author{
${ }^{1}$ Centro de Ciências Agrárias, Universidade Federal da Paraíba, Areia, PB, Brasil. \\ ${ }^{2}$ Centro de Ciências Humanas, Sociais e Agrárias, Universidade Federal da Paraíba, Bananeiras, PB, Brasil. \\ ${ }^{3}$ Empresa Estadual de Pesquisa Agropecuária da Paraíba S. A., Alagoinha, PB, Brasil. \\ ${ }^{4}$ Programa de Doutorado Integrado em Zootecnia, Universidade Federal da Paraíba, Areia, PB, Brasil. \\ ${ }^{5}$ Programa de Pós-graduação em Sistemas Agrosilvipastoris, Universidade Federal de Campina Grande, Patos, PB, Brasil.
}

ABSTRACT - This experiment was carried to evaluate the effect of forage cactus with different fiber sources (elephant grass hay [EGH], corn straw [CS], hay of cassava shoots [HCS], fresh sugarcane bagasse [FSB], and hydrolyzed sugarcane bagasse [HSB]) on intake, apparent digestibility and macrobiotic protein production of cows. Five cows with $265 \mathrm{~kg}$ average body weight, $4.95 \mathrm{~kg}$ average daily milk yield and $5.22 \mathrm{~kg} \mathrm{4 \%}$ fat-corrected milk yield were randomly allocated to a $5 \times 5$ Latin square design. The animals fed cactus associated with CS, EGH and HCS showed higher intake of DM and nutrients. However, regarding the digestibility, diets with sugarcane bagasse showed higher digestibility compared with those with CS and hay. For microbial protein, the excretion of purine derivatives, synthesis of microbial $\mathrm{N}$ and microbial protein production were higher in the treatment with CS than in the treatment with sugarcane bagasse. On the other hand, the treatment with EGH and HCS did not have statistical differences compared with the other cases. The mean efficiency of microbial protein synthesis of the experiment was $131 \mathrm{~g}$ microbial crude protein $/ \mathrm{kg}$ of TDN. The treatment with CS showed better efficiency; however, it was statistically superior only compared with FSB. The other treatments did not show statistical difference compared with the other cases. Diets with cactus associated with corn straw, hay of elephant grass or hay of cassava shoots provide higher intake of dry matter and nutrients and better metabolic response compared with diets with cactus associated with sugarcane bagasse for lactating Sindhi cows.

Key Words: Nopalea cochenillifera, purine derivatives, roughage, zebu

\section{Introduction}

The productivity of ruminants depends on their ability to consume and extract useful energy from the available foods. According to Zeoula and Geron (2006), intake is the component that plays the role of greatest importance in animal nutrition, as it will determine the amount of ingested nutrient and hence performance. In addition to the nutrient intake, determining the digestibility of feeds or diets is important because it corresponds to the portion of feed consumed that was not excreted in the stools.

The microbial protein synthesis in the rumen is primarily responsible for meeting the protein requirements of ruminants and this depends largely on the availability of carbohydrates and nitrogen $(\mathrm{N})$ in the rumen, and an asynchronism results in inefficient use of fermentable

Received October 31, 2013 and accepted April 28, 2014

Corresponding author: carla@cca.ufpb.br

http://dx.doi.org/10.1590/S1516-35982014001000004

Copyright (@) 2014 Sociedade Brasileira de Zootecnia. This is an Open Access article distributed under the terms of the Creative Commons Attribution Non-Commercial License, which permits unrestricted non-commercial use, distribution, and reproduction in any medium, provided the original work is properly cited. substrates and reduced synthesis of microbial protein (NRC, 2001). The lack of simple and accurate methods for measuring microbial protein is an obstacle to its deeper understanding. According to Chen and Gomes (1992), the method of excretion of purine derivatives overcomes other methods to determine microbial protein production for being simple, non-invasive and only requiring a total urine collection. In recent years, research has been developed with the aim of making this technique simpler, from a single sampling of urine for about four hours after morning feeding of animals, called spot collection, using serum creatinine as a marker to estimate the urine volume.

In the Brazilian Northeast, forage cactus (Opuntia ficusindica Mill Nopalea cochenillifera Dyck) is one of the main forages used in dairy cattle feeding, especially in the dry season. All cactus cultivars are rich in non-structural carbohydrates and have a high moisture content. The main limitations of this cactus are the nitrogen compounds and neutral detergent fiber content, requiring supplementation with other sources of nitrogen and fiber. Soluble urea, a result of the high carbohydrates content, is an important alternative for protein correction of forage cactus, besides 
its being associated with a source of forage with high effective fiber.

Zebu are rustic animals well-suited to adverse conditions of tropical regions, and Sindi is the recommended breed for the northeast of Brazil.

Therefore, the objective of this study was to evaluate the effect of combining forage cactus with different forages on intake, digestibility and estimated production and efficiency of microbial protein synthesis in Sindhi cows.

\section{Material and Methods}

The experiment was conducted at the Alagoinha Experimental Station, belonging to the State Company for Agricultural Research of Paraíba State (EMEPA, Empresa Estadual de Pesquisa Agropecuária da Paraíba S.A.), located in the municipality of Alagoinha/PB, Brazil.

Five Sindi cows (265 kg average live weight, first order of delivery, between 60 and 90 days of lactation) were housed in individual stalls provided with individual troughs and drinkers for feed-intake control. The experimental design was a Latin square with five cows, five periods and five treatments. Each period lasted 15 days during which 10 days were for the animals to adapt to diets and five for collecting data and samples, totaling 75 days of experimental period. The experimental diets were formulated according to the NRC (2001) to meet the requirements of animals of low-yield potential, average $6 \mathrm{~kg}$ milk/day, containing around $10.3 \% \mathrm{CP}$ in their formulation. The feed was given to the animals twice daily $(6.00 \mathrm{~h}$ and $15.00 \mathrm{~h})$ as a complete diet, allowing for leftovers of 10 to $20 \%$ of total dry matter provided as a means to maintain the levels of ingredients in the diets. Animals were weighed at the beginning and end of the harvest period, thereby determining the change in weight according to the experimental periods.

The experimental treatments consisted of spineless cactus (Nopalea cochenillifera Salm-Dyck) Miúda (variety), associated with different fiber sources (Tables 1 and 2). The treatment of hydrolyzed sugarcane bagasse consisted of three kilos of hydrated lime dissolved in $50 \mathrm{~L}$ of water for every $100 \mathrm{~kg}$ of bagasse (Mattos et al., 2000).

At harvest time samples of feed ingredients and leftovers were taken and at the end of each period composite samples were made per animal and stored at $-20{ }^{\circ} \mathrm{C}$ to be analyzed later. The dry matter (DM), organic matter (OM), crude protein $(\mathrm{CP})$, ether extract (EE) and lignin contents were determined according to Silva and Queiroz (2002); concentrations of NDF and ADF were measured according to the non-sequential procedures of Van Soest et al. (1991) using amylase because of the high content of non-fiber carbohydrates in the forage cactus, but not sodium sulfite.

On the 11th and 13th days of each experimental period before food supply in the morning and afternoon, a fecal sample was collected directly from the rectum of animals and stored at $-20{ }^{\circ} \mathrm{C}$ for further analysis and determination of diet digestibility. At the end of the experiment samples of ingredients, leftovers and feces were thawed and dried in a forced-air oven at $55{ }^{\circ} \mathrm{C}$ for 72 to 96 hours, with the

Table 1 - Proportions of ingredients in the diet

\begin{tabular}{|c|c|c|c|c|c|}
\hline \multirow[b]{2}{*}{ Ingredients } & \multicolumn{5}{|c|}{ Experimental diets } \\
\hline & Forage + EGH & Forage $+\mathrm{CS}$ & Forage $+\mathrm{HCS}$ & Forage + FSB & Forage $+\mathrm{HSB}$ \\
\hline Forage cactus ${ }^{1}$ & 499.0 & 471.0 & 500.0 & 500.0 & 461.0 \\
\hline Elephant grass hay ${ }^{1}$ & 440.0 & - & - & - & - \\
\hline Corn straw ${ }^{1}$ & - & 448.0 & - & - & - \\
\hline Hay of cassava shoots ${ }^{1}$ & - & - & 450.0 & - & - \\
\hline Fresh sugarcane bagasse $^{1}$ & - & - & - & 399.0 & - \\
\hline Hydrolyzed sugarcane bagasse ${ }^{1}$ & - & - & - & - & 438.0 \\
\hline Soybean meal ${ }^{1}$ & 30.0 & 50.0 & 20.0 & 70.0 & 70.0 \\
\hline Urea + ammonium sulfate ${ }^{1}$ & 16.0 & 16.0 & 15.0 & 16.0 & 16.0 \\
\hline Mineral $\operatorname{mix}^{1}$ & 15.0 & 15.0 & 15.0 & 15.0 & 15.0 \\
\hline \multicolumn{6}{|l|}{ Nutritional composition } \\
\hline Dry matter (g/kg fresh weight) & 194.6 & 204.2 & 190.0 & 212.9 & 195.6 \\
\hline Organic matter ${ }^{1}$ & 837.5 & 854.1 & 864.7 & 873.7 & 869.7 \\
\hline Crude protein ${ }^{1}$ & 113.1 & 123.4 & 105.7 & 119.4 & 117.3 \\
\hline NDFap $^{1}$ & 502.5 & 473.7 & 430.9 & 504.0 & 520.7 \\
\hline Acid detergent fiber ${ }^{1}$ & 374.0 & 316.8 & 344.1 & 363.7 & 372.3 \\
\hline Lignin $^{1}$ & 69.0 & 54.7 & 94.0 & 66.1 & 71.1 \\
\hline Ether extract ${ }^{1}$ & 17.8 & 18.4 & 16.7 & 17.7 & 14.6 \\
\hline $\mathrm{NFCap}^{1}$ & 239.7 & 272.4 & 337.0 & 269.4 & 251.1 \\
\hline Total digestible nutrients ${ }^{1,2}$ & 597.6 & 642.2 & 620.9 & 605.7 & 599.0 \\
\hline
\end{tabular}

${ }^{1} \mathrm{~g} / \mathrm{kg} \mathrm{DM}$.

2 Patterson et al. (2000)

EGH - elephant grass hay; CS - corn straw; HCS - hay of cassava shoots; FSB - fresh sugarcane bagasse; HSB - hydrolyzed sugarcane bagasse.

NDFap - neutral detergent fiber corrected for ash and protein; NFCap - non-fibrous carbohydrates corrected for ash and protein. 
Table 2 - Chemical composition of the nutrients in ingredients of experimental diets

\begin{tabular}{lccccccc}
\hline & Forage & EGH & CS & FSB & HSB & HCS & $\begin{array}{c}\text { Soybean } \\
\text { meal }\end{array}$ \\
\hline $\mathrm{DM}$ & 110.8 & 848.0 & 826.3 & 709.6 & 526.3 & 835.1 & 865.0 \\
$\mathrm{OM}^{1}$ & 843.9 & 882.1 & 914.1 & 966.9 & 946.7 & 942.0 & 943.0 \\
$\mathrm{MM}^{1}$ & 156.1 & 111.9 & 86.0 & 58.0 & 33.1 & 53.3 & 56.9 \\
$\mathrm{CP}^{1}$ & 58.3 & 51.6 & 53.1 & 18.5 & 17.3 & 52.2 & 539.2 \\
$\mathrm{EE}^{1}$ & 18.9 & 17.3 & 18.4 & 16.2 & 09.3 & 14.9 & 25.3 \\
$\mathrm{NDF}^{1}$ & 315.0 & 774.7 & 709.7 & 833.0 & 833.4 & 601.0 & 148.7 \\
$\mathrm{ADF}^{1}$ & 249.7 & 559.4 & 432.4 & 579.3 & 569.6 & 482.4 & 109.9 \\
$\mathrm{NFC}^{1}$ & 427.5 & 44.3 & 132.8 & 99.2 & 86.6 & 273.8 & 229.9 \\
$\mathrm{LIG}^{1}$ & 34.0 & 117.2 & 84.5 & 120.4 & 124.0 & 170.4 & 15.2 \\
\hline
\end{tabular}

${ }^{1} \mathrm{~g} / \mathrm{kg} \mathrm{DM}$.

EGH - elephant grass hay; CS - corn straw; HCS - hay of cassava shoots; FSB - fresh sugarcane bagasse; HSB - hydrolyzed sugarcane bagasse.

exception of forage cactus, which required a longer period. These were then processed in a grinder with sieve fitted with a $1 \mathrm{~mm}$ sieve and stored for subsequent analysis.

The indigestible neutral detergent fiber was used as internal marker to determine the apparent digestibility of the feed, which was packed in bags made of non-woven fabric (TNT fabric) $\left(100 \mathrm{~g} / \mathrm{m}^{2}\right)$ according to the methodology described by Casali et al. (2008), except for the feces, which were processed through a $1 \mathrm{~mm}$ sieve.

The total carbohydrates (TC) were calculated according to Sniffen et al. (1992): TC $=100-(\% \mathrm{CP}+\% \mathrm{EE}+\% \mathrm{ash})$. The content of non-fiber carbohydrates (NFC) was obtained by the formula NFC $=$ TC - NDFap, in which NDFap $=$ neutral detergent fiber corrected for ash and protein. The total digestible nutrients (TDN) were calculated by the formula $\mathrm{TDN}=(\mathrm{CPI}-$ fecalCP $)+(\mathrm{TCI}-$ fecalTC $)+2.25$ $(\mathrm{EEI}-$ fecalEE $)$, in which $\mathrm{CPI}=$ crude protein intake; $\mathrm{TCI}=$ total carbohydrate intake; and EEI = ether extract intake.

On the 12th day of each experimental period the urine spot collection was performed for analysis of allantoin in urine by the colorimetric method, according to the technique described by Chen and Gomes (1992); the same procedure was performed in milk without protein. Analyses of creatinine and uric acid in urine were performed using commercial kits (Labtest). The average daily urine volume was estimated for each animal by multiplying their body weight by the daily excretion of creatinine $(\mathrm{mg} / \mathrm{kg} \mathrm{BW})$ and dividing that product by the creatinine concentration $(\mathrm{mg} / \mathrm{L})$ in the spot urine, using the value of $24.4 \mathrm{mg} / \mathrm{kg}$ of BW creatinine found in cows by Pereira (2003) in the early and middle thirds of the lactation period.

The purine derivatives were calculated by adding allantoin and uric acid in urine and milk allantoin, expressed in mmol/day. The microbial purines absorbed and the intestinal flow of nitrogenous compounds were calculated from the equations described by Chen and
Gomes (1992). The estimate of microbial CP (MCP) was obtained by multiplying the synthesis of microbial nitrogen by 6.25 , while the efficiency of microbial protein synthesis was determined by the formula: EMCPS $(\mathrm{g} / \mathrm{kg})=\mathrm{MCP}$ $(\mathrm{g}) / \mathrm{TDNI}(\mathrm{kg})$, in which TDNI $=$ intake of total digestible nutrients.

The animals were divided in a in $5 \times 5$ Latin square design with five treatments and five experimental periods, according to the model: Yijk $=\mathrm{m}+\mathrm{ai}+\mathrm{bj}+\mathrm{dk}+$ eijk, in which $\mathrm{m}=$ overall constant; ai $=$ fixed effect related to treatment $\mathrm{i} ; \mathrm{bj}=$ random effect related to animal $\mathrm{j} ; \mathrm{dk}=$ random effect related to trial period $\mathrm{k}$; and eijk $=$ random error associated with each observation, assumption NID $\left(0, \mathrm{~s}^{2}\right)$

The analysis of variance was performed using the $\mathrm{SAS}^{\circledR}$ statistical software, version 8.2 for Windows ${ }^{\circledR}$, and the means for DM intake and nutrients, apparent digestibility and microbial protein production were compared by Tukey's test at $5 \%$ probability.

\section{Results}

Dry matter intake expressed as $\mathrm{kg} /$ day, $\% \mathrm{BW}$ and $\mathrm{g} / \mathrm{BW}^{0.75}$ and $\mathrm{OM}$ intake were higher $(\mathrm{P}<0.05)$ for animals fed forage associated with EGH, CS or HCS compared with the treatments with sugarcane bagasse (Table 4).

Animals fed forage associated with CS had greater $(\mathrm{P}<0.05) \mathrm{CP}$ intake compared with those on treatments HCS, FSB or HSB. The treatment with forage associated with EGH, although not different from treatments with CS and HCS, was higher compared with the treatment with FSB and HSB.

Lower NDF intake $(\mathrm{kg} /$ day and $\% \mathrm{BW})(\mathrm{P}<0.05)$ was observed for treatments with forage associated with FSB and HSB compared with the treatments with CS and EGH; on the other hand, the treatment with HCS showed no statistical difference $(\mathrm{P}>0.05)$ compared with the others.

Increased NFC intake $(\mathrm{P}<0.05)$ was observed for animals fed forage associated with HCS, compared with the other treatments, which may be explained by the lower NDF and higher non-fiber carbohydrates in this treatment.

The intake of total digestible nutrients was higher $(\mathrm{P}<0.05)$ in animals fed forage associated with $\mathrm{EGH}, \mathrm{CS}$ or HCS than those fed HSB; however, those animals fed FSB showed no statistical difference compared with the others.

Higher DM digestibility was observed $(\mathrm{P}<0.05)$ in the diets of animals fed FSB compared with the treatments with EGH, CS and HCS; however, the diets containing forage associated with HSB showed no difference $(\mathrm{P}>0.05)$ compared with those containing FSB and HCS (Table 4). 
As regards NDF digestibility, the treatment with HCS was significantly lower $(\mathrm{P}<0.05)$ compared with all other treatments. On the other hand, diets with EGH and CS were statistically lower $(\mathrm{P}<0.05)$ compared with the FSB diet.

The allantoin excretion in the urine, purine derivatives, absorbed purines, synthesis of microbial nitrogen and microbial crude protein (Table 5) showed similar behaviors, that is, the respective variables were higher $(\mathrm{P}<0.05)$ for treatment with CS compared with the treatments with sugarcane bagasse. On the other hand, treatments with EGD and HCS showed no statistical difference $(\mathrm{P}>0.05)$ compared with the others.

The treatment with CS had higher milk allantoin excretion $(\mathrm{P}<0.05)$ than the treatment with HSB; the same behavior was observed for milk yield in the experiment (Table 3).

Table 3 - Milk yield and 4\% fat-corrected milk yield of Sindhi breed cows fed diets with forage cactus associated with different fiber sources

\begin{tabular}{lcccc}
\hline & & \multicolumn{2}{c}{ Experimental diets } \\
\cline { 2 - 5 } & Forage + EGH & Forage + CS & Forage + HCS & Forage + FSB \\
\hline Milk yield (kg/day) & 5.24 & 6.09 & 4.76 & 4.62 \\
$4 \%$ fat-corrected milk yield (kg/day) & 5.94 & 6.23 & 5.00 & 4.04 \\
\hline
\end{tabular}

EGH - elephant grass hay; CS - corn straw; HCS - hay of cassava shoots; FSB - fresh sugarcane bagasse; HSB - hydrolyzed sugarcane bagasse.

Table 4 - Average intakes and digestibilities of chemical components and coefficients of variation (CV) of Sindhi cows fed diets with forage cactus associated with different fiber sources

\begin{tabular}{|c|c|c|c|c|c|c|}
\hline & \multicolumn{5}{|c|}{ Experimental diets } & \multirow[b]{2}{*}{$\mathrm{CV}(\%)$} \\
\hline & Forage $+\mathrm{EGH}$ & Forage + CS & Forage $+\mathrm{HCS}$ & Forage + FSB & Forage + HSB & \\
\hline \multicolumn{7}{|c|}{ Intake } \\
\hline DM (kg/day) & $8.67 \mathrm{a}$ & $9.08 \mathrm{a}$ & $8.5 \mathrm{a}$ & $6.22 b$ & $5.63 b$ & 13.07 \\
\hline DM (\%BW) & $3.33 \mathrm{a}$ & $3.45 \mathrm{a}$ & $3.23 \mathrm{a}$ & $2.36 \mathrm{~b}$ & $2.14 \mathrm{~b}$ & 12.45 \\
\hline $\mathrm{DM}\left(\mathrm{g} / \mathrm{BW}^{0.75}\right)$ & $133.77 \mathrm{a}$ & $138.82 \mathrm{a}$ & $129.99 a$ & $95.08 \mathrm{~b}$ & $86.12 b$ & 12.56 \\
\hline OM (kg/day) & $7.45 \mathrm{a}$ & $7.88 \mathrm{a}$ & $7.48 \mathrm{a}$ & $5.54 b$ & $4.93 b$ & 13.41 \\
\hline CP (kg/day) & $0.98 \mathrm{ab}$ & $1.15 \mathrm{a}$ & $0.89 \mathrm{bc}$ & $0.73 \mathrm{c}$ & $0.66 \mathrm{c}$ & 12.88 \\
\hline EE (kg/day) & $0.16 \mathrm{a}$ & $0.15 \mathrm{ab}$ & $0.15 \mathrm{ab}$ & $0.11 b c$ & $0.09 \mathrm{c}$ & 15.62 \\
\hline NDF (kg/day) & $4.21 \mathrm{a}$ & $4.20 \mathrm{a}$ & $3.44 \mathrm{ab}$ & $3.01 \mathrm{~b}$ & $2.67 \mathrm{~b}$ & 14.24 \\
\hline NDF (\%BW) & $1.62 \mathrm{a}$ & $1.59 \mathrm{a}$ & $1.30 \mathrm{ab}$ & $1.14 \mathrm{~b}$ & $1.01 \mathrm{~b}$ & 14.06 \\
\hline NFC (kg/day) & $2.09 \mathrm{bc}$ & $2.35 b$ & $3.04 \mathrm{a}$ & $1.68 \mathrm{c}$ & $1.51 \mathrm{c}$ & 14.44 \\
\hline TDN (kg/day) & $4.11 \mathrm{a}$ & $4.10 \mathrm{a}$ & $4.20 \mathrm{a}$ & $3.71 \mathrm{ab}$ & $3.01 \mathrm{~b}$ & 12.79 \\
\hline \multicolumn{7}{|c|}{ Digestibility } \\
\hline DM & $52.00 \mathrm{c}$ & $50.12 c$ & $53.07 \mathrm{bc}$ & $63.99 \mathrm{a}$ & $58.45 \mathrm{ab}$ & 5.04 \\
\hline OM & $52.48 \mathrm{~b}$ & $51.28 \mathrm{~b}$ & $53.94 b$ & $64.92 \mathrm{a}$ & $59.71 \mathrm{a}$ & 4.73 \\
\hline $\mathrm{CP}$ & $70.06 \mathrm{bc}$ & $65.34 \mathrm{~cd}$ & $61.99 \mathrm{~d}$ & $79.15 \mathrm{a}$ & $74.78 \mathrm{ab}$ & 5.45 \\
\hline $\mathrm{EE}$ & $64.71 \mathrm{ab}$ & $47.94 \mathrm{c}$ & $58.42 \mathrm{bc}$ & $74.40 \mathrm{a}$ & $68.06 \mathrm{ab}$ & 9.51 \\
\hline NDF & $38.00 \mathrm{~b}$ & $36.20 \mathrm{~b}$ & $27.29 \mathrm{c}$ & $48.96 \mathrm{a}$ & $44.86 \mathrm{ab}$ & 11.19 \\
\hline NFC & $72.31 b$ & $70.84 b$ & $83.73 a$ & $86.52 \mathrm{a}$ & 77.59ab & 7.23 \\
\hline
\end{tabular}

Means followed by different letters in the row differ by Tukey's test $(\mathrm{P}<0.05)$.

EGH - elephant grass hay; CS - corn straw; HCS - hay of cassava shoots; FSB - fresh sugarcane bagasse; HSB - hydrolyzed sugarcane bagasse.

Table 5 - Daily urinary excretion of uric acid (UA), milk allantoin (MAl), allantoin in urine (UAl), purine derivatives (PD), absorbed purines (AP), synthesis of microbial nitrogen (SMN), microbial crude protein synthesis (MCPS), efficiency of microbial crude protein synthesis (EMCPS) and coefficients of variation (CV) of Sindhi cows fed diets with forage cactus associated with different fiber sources

\begin{tabular}{|c|c|c|c|c|c|c|}
\hline & \multicolumn{5}{|c|}{ Experimental diets } & \multirow[b]{2}{*}{$\mathrm{CV}(\%)$} \\
\hline & Forage $+\mathrm{EGH}$ & Forage $+\mathrm{CS}$ & Forage $+\mathrm{HCS}$ & Forage + FSB & Forage + HSB & \\
\hline UA (mmol/day) & $10.45 b c$ & $15.64 \mathrm{a}$ & $12.12 \mathrm{ab}$ & $7.51 \mathrm{c}$ & $7.85 \mathrm{c}$ & 17.05 \\
\hline MAl (mmol/day) & $2.35 \mathrm{ab}$ & $2.67 \mathrm{a}$ & $2.23 \mathrm{ab}$ & $2.26 \mathrm{ab}$ & $1.90 \mathrm{~b}$ & 15.57 \\
\hline UAl (mmol/day) & $113.21 \mathrm{ab}$ & $128.16 \mathrm{a}$ & $117.29 \mathrm{ab}$ & $82.85 b$ & $87.93 b$ & 18.56 \\
\hline PD (mmol/day) & $126.02 \mathrm{ab}$ & $146.48 \mathrm{a}$ & $131.64 \mathrm{ab}$ & $92.63 b$ & $97.67 \mathrm{~b}$ & 17.45 \\
\hline AP (mmol/day) & $119.09 \mathrm{ab}$ & $142.53 \mathrm{a}$ & $125.31 \mathrm{ab}$ & $79.23 b$ & $85.25 b$ & 22.00 \\
\hline SMN (g N/day) & $86.58 \mathrm{ab}$ & $103.62 \mathrm{a}$ & $91.10 \mathrm{ab}$ & $57.61 b$ & $61.98 b$ & 21.99 \\
\hline MCPS (g/day) & $541.16 \mathrm{ab}$ & $647.64 \mathrm{a}$ & $569.42 \mathrm{ab}$ & $360.05 b$ & $387.40 \mathrm{~b}$ & 21.99 \\
\hline EMCPS (g MCP/kg TDN) & $132.23 \mathrm{ab}$ & $158.17 \mathrm{a}$ & $136.34 \mathrm{ab}$ & $96.47 \mathrm{~b}$ & $131.88 \mathrm{ab}$ & 20.39 \\
\hline
\end{tabular}

Means followed by different letters in the row differ by Tukey's test $(\mathrm{P}<0.05)$.

EGH - elephant grass hay; CS - corn straw; HCS - hay of cassava shoots; FSB - fresh sugarcane bagasse; HSB - hydrolyzed sugarcane bagasse. 
The urinary excretion of allantoin ranged from 82.85 to $128.16 \mathrm{mmol} /$ day, averaging $105.88 \mathrm{mmol} /$ day.

The average EMCPS of the experiment was $131 \mathrm{~g} \mathrm{MCP/}$ $\mathrm{kg}$ TDN. The treatment with CS was the most efficient; however, it was statistically higher $(\mathrm{P}<0.05)$ only in relation to the FSB, while other treatments showed intermediate behavior.

The treatment with FSB had the lowest EMCPS (96.47 g of $\mathrm{MCP} / \mathrm{kg}$ of TDN); this result is probably related to the fiber quality of FSB, which may have led to a lower passing rate and hence lower flow of protein to the abomasum.

\section{Discussion}

As regards dry matter intake, similar results to that reported herein were found by Mattos et al. (2000), wherein lower DMI was observed for Girolando cows fed forage associated with fresh and hydrolyzed sugarcane bagasse compared with treatments in which the forage was associated with sorghum silage and saccharin.

The higher DM intake $(\mathrm{P}<0.05)$ observed in this experiment in the treatments with EGH, CS and HCS is probably due to the greater palatability of these diets and fiber quality in diets with sugarcane bagasse, which had a high lignin content (Table 2), which may have caused a lower passage rate in the rumen-reticulum coupled with the filling effect, a factor that in these cases reduces intake by the animal.

A fact that should be stressed is the particle size of sugarcane bagasse; although it passed through the forage machine before being offered to the animals, it still remained with a larger particle size than the corn hay and stover, which also may have influenced the DMI. According to Allen (2000), the flow in the rumen-reticulum is limited by size and density of food particles, which leads to stretching of these organs. These authors also emphasize that when the stretch in the rumen-reticulum limits the DMI, a reduction in the particle size of the forage may result in increased DMI if the density of the consumed particles or the time available for rumination increases.

This difference in CP intake may be due to the higher DM intake in these treatments and consequently the nutrients, as well as higher content of nutrients mainly in the treatment with CS (Table 1). Although all diets were formulated to contain on average $10 \% \mathrm{CP}$, after laboratory tests at the end of the experiment some ingredients differed in their composition of nutrients, especially in CP and NDF.

The effect of diets on NDF intake may be caused by reduced DMI, and probably a result of greater rejection of these diets by the animals, besides the effect of bagasse particle size. According to Allen (2000), the physical and chemical characteristics of diet ingredients and their interactions can have a great effect on the DMI. In this case, the amount of ingested nutrients will be changed as well.

Unlike the results found herein, Silva et al. (2007) found no difference in NFC and TDN intake of Holstein cows fed diets with forage cactus associated with different forages, possibly because there was no difference in DMI and nutrient intake by the animals in the study, besides the similarity in diet composition.

Although the form of providing the feed in this experiment was in a complete diet, the different fiber sources associated with forage cactus affected the digestibility of nutrients and DM (Table 4). According to Van Soest (1994), digestibility coefficients can be relatively constant for certain environmental conditions, but the food can be more or less digestible if there is variation in intake or separate provision.

Although the diets with sugarcane bagasse showed higher digestibility, this was not sufficient to ensure the highest performance of the animals (Table 3), probably reflecting the lower intake. The characteristics of sugarcane bagasse fiber as a probable effect of rumen fill might have made this material remain longer in the rumen than the other diets, which led to a higher digestibility at the end, though possibly with lower degradability, which in this case also affected the intake.

Although the diet with HCS had lower NDF contents $(42.40 \%)$ in its composition, the ADF percentage is higher than NDF, whose most influential component is lignin, which may have led to lower digestibility.

Leão (2007), working on increasing levels of cassava shoots hay in diets based on sugarcane $+1 \%$ urea $(0,25$, 50,75 and $100 \% \mathrm{DM}$ ), found decreased digestibility for all nutrients, besides increased DM intake at the level of $65 \%$ hay of cassava shoots. According to the authors, this phenomenon can be explained by the increased DM intake, which decreases the digestibility of nutrients, besides the direct ADF effect of cassava shoots hay on the digestibility of its components.

The acid detergent fiber fraction is composed of cellulose and lignin; as the latter component is increased the digestibility of DM, NDF and ADF decreases. The hay of cassava shoots has a high lignin content, which in this experiment was on average $17.04 \%$ (Table 2). Thus, although this was the treatment with the lowest NDF content, it had a high amount of lignin, a fact that may have contributed to reduced digestibility of the treatment in question. Van Soest (1994) points out that lignin is recognized as the main factor limiting digestibility, but this does not affect all components. 
Pessoa et al. (2005) found mean coefficients of digestibility of $67.16,68.96,77.24,52.97,53.42$, and $73.40 \%$ for DM, OM, CP, EE, NDF and NFC in an experiment using forage cactus. However, the NDF content in the aforementioned study was $30.30 \%$ below the value reported in the present study, whose NDF of treatments ranged from 42.40 to $52.70 \%$. According to Van Soest (1994), decreased digestibility is proportional to the NDF and rate of passage and inversely related to the rate of digestion and therefore the characteristics of the cell wall are of great importance. This refers basically to the cell wall lignification, because as lignification increases, digestibility decreases.

As the microbial protein synthesis is dependent on the availability of substrate for rumen microorganisms, mainly protein and carbohydrates, the lower DM intake in diets with sugarcane bagasse possibly influenced the results, which reflected also in milk production (Table 3 ).

According to Gonda and Lindberg (1997), milk production influences the concentration and quantity of allantoin in milk, which probably accounts for the results found here.

Barbosa et al. (2006) observed an average of 92.33 $\mathrm{mmol} /$ day of allantoin in Nellore cows. According to Barbosa et al. (2006), data described in the literature indicate that the level of allantoin in cows is not constant in all physiological stages and dietary treatments, which also seems to happen in zebu cows.

The NRC (2001) established an average microbial protein synthesis efficiency of $130 \mathrm{~g} \mathrm{MCP} / \mathrm{kg}$ of TDN; however, Valadares Filho et al. (2006) recommends $120 \mathrm{~g}$ $\mathrm{MCP} / \mathrm{kg}$ of TDN as a reference for tropical conditions, i.e., the findings of the present study are consistent with the literature.

Lower passage rates result in lower ruminal dilution rate, and according to Bach et al. (2005), higher microbial protein synthesis and EMCPS are associated with higher rates of dilution because microbial species with higher growth rates are selected and the maintenance requirements of rumen microorganisms are diluted. Moreover, the microbial protein synthesis increases with the availability of organic matter; hence the higher values of microbial protein and EMCPS in diets with CS, EGH and HCS. The treatment with HSB showed lower microbial protein synthesis; however, its EMCPS was within the recommended by NRC (2001), which was also a result of lower TDN intake.

\section{Conclusions}

The different fiber sources evaluated as alternative to diets with forage cactus influence nutrient intake, apparent digestibility and microbial protein synthesis. The use of forage associated with corn straw allows for better metabolic responses than its association with sugarcane bagasse as a fiber source; however, elephant grass and hay of cassava shoots are also a good alternative for use as fiber source in diets based on forage cactus for lactating Sindi cows.

\section{References}

Allen, M. S. 2000. Effects of diet on short-term regulation of feed intake by lactating dairy cattle. Journal of Dairy Science 83:1598-1624.

Bach, A.; Calsamiglia, S. and Stern, M. D. 2005. Nitrogen metabolism in the rumen. Journal of Dairy Science 88(E. Suppl.):E9-E21.

Barbosa, A. M.; Valadares, R. F. D.; Valadares Filho, S. C.; Véras, R. M. L.; Leão, M. I.; Detmann, E.; Paulino, M. F.; Marcondes, M. I. and Souza, M. A. 2006. Efeito do período de coleta de urina, dos níveis de concentrado e de fontes protéicas sobre a excreção de creatinina, de uréia e de derivados de purina e a produção microbiana em bovinos Nelore. Revista Brasileira de Zootecnia 35:870-877.

Casali, A. O.; Detmann, E.; Valadares Filho, S. C.; Pereira, J. C.; Henriques, L. T.; Freitas, S. G. and Paulino, M. F. 2008. Influência do tempo de incubação e do tamanho de partículas sobre os teores de compostos indigestíveis em alimentos e fezes bovinas obtidos por procedimentos in situ. Revista Brasileira de Zootecnia 37:335-342.

Chen, X. B. and Gomes, M. J. 1992. Estimation of microbial protein supply to sheep and cattle based on urinary excretion of purine derivatives - an overview of technical details. International Feed Research Unit. Rowett Research Institute, Aberdeen, UK. (Occasional publication).

Gonda, H. L. and Lindberg, J. E. 1997. Effect of diet on milk allantoin and its relationship with urinary allantoin in dairy cows. Journal of Dairy Science 80:364-373.

Leão, V. P. C. 2007. Feno da parte aérea da mandioca associada a mistura cana-de-açucar e ureia para ovinos. Dissertação (M.Sc.). Universidade Estadual do Sudoeste da Bahia, Vitória da Conquista.

Mattos, L. M. E.; Ferreira, M. A.; Santos, D. C.; Lira, M. A.; Santos, M. V. F.; Batista, A. M. V. and Véras, A. S. C. 2000. Associação da palma forrageira (Opuntia ficus indica Mill) com diferentes fontes de fibra na alimentação de vacas 5/8 Holandês-Zebu em lactação. Revista Brasileira de Zootecnia 29:2128-2134.

NRC - National Research Council. 2001. Nutrient requirements of dairy cattle. 7th ed. National Academy Press, Washington, D.C.

Patterson, T.; Klopfenstein, T. J.; Milton, T. and Brink, D. R. 2000. Evaluation of the 1996 beef cattle NRC model predictions of intake and gain for calves fed low or medium energy density diets. Nebraska BeefCattle Reports. Available at: < http://digitalcommons. unl.edu/animalscinbcr/385>. Accessed on: Feb. 5, 2012.

Pereira, M. L. A. 2003. Proteína na dieta de vacas nos terços inicial e médio de lactação. Tese (D.Sc.). Universidade Federal de Viçosa, Viçosa, MG, Brasil.

Pessoa, R. A. S.; Ferreira, M. A.; Lima, L. E.; Lira, M. A.; Véras, A. S. C.; Silva, A. E. V.; Sosa, M. Y.; Azevedo, M.; Miranda, K. F.; Silva, F. M. and Melo, A. A. S. 2005. Vacas leiteiras submetidas a diferentes estratégias alimentares. Digestibilidade e balanço de energia. Acta Scientarium Animal Science 27:253-260.

Silva, D. J. and Queiroz, A. C. 2002. Análise de alimentos (métodos químicos e biológicos). 2.ed. Universidade Federal de Viçosa, Imprensa Universitária, Viçosa, MG.

Silva, R. R.; Ferreira, M. A.; Véras, A. S. C.; Ramos, A. O.; Melo, A. A. S. and Guimarães, A. V. 2007. Palma forrageira (Opuntia ficus indica Mill) associada a diferentes volumosos em dietas para vacas da raça Holandesa em lactação. Acta Scientarium Animal Science 29:317-324.

Sniffen, C. J.; O'Connor, J. D.; Van Soest, P. J.; Fox, D. G. and Russell, J. B. 1992. A net carbohydrate and protein system for evaluating 
cattle diets; II. Carbohydrate and protein availability. Journal of Animal Science 70:3562-3577.

Valadares Filho, S. C.; Pina, D. S. and Chizzotti, M. L. 2006. Degradação ruminal da proteína dos alimentos e síntese de proteína microbiana. p.13-46. In: Exigências nutricionais de zebuínos e tabelas de composição de alimentos BR-Corte. Valadares Filho, S. C.; Paulino, P. V. R.; Magalhães, K. A., eds. UFV, DZO, Viçosa, MG.
Van Soest, P. J.; Robertson, J. B. and Lewis, B. A. 1991. Methods for dietary fiber, neutral detergent fiber, and nonstarch polysaccharides in relation to animal nutrition. Journal of Animal Science 74:3583-3597.

Van Soest, P. J. 1994. Nutritional ecology of the ruminant. 2nd ed. Cornell University Press, Ithaca.

Zeoula, L. M. and Geron, L. J. V. 2006. Vitaminas. p.355-392. In: Nutrição de ruminantes. Berchielli, T. T.; Pires, A. V. and Oliveira, S. G., eds. FUNEP, Jaboticabal. 